\title{
About the biology of Steraspis infuscata Théry and data on additional species of Steraspis collected in Benin (Coleoptera, Buprestidae)
}

\author{
by Jean-François VAYSSIÈRES* \& Charles L. BELLAMY** \\ * Centre International de Recherche Agronomique pour le Développement - UPR HortSys / International \\ Institute of Tropical Agriculture, 08 BP 0932, Cotonou, Benin <j.vayssieres@cgiar.org> \\ ** Plant Pest Diagnostic Center / California Dept of Food \& Agriculture, 3294 Meadowview Road, \\ Sacramento, California (CA), 95832, USA <cbellamy@cdfa.ca.gov>
}

\begin{abstract}
Four species of Steraspis Dejean, 1883, have been collected in the centre and the north of Benin in West Africa: Steraspis fastuosa Gerstaecker, 1871, Steraspis infuscata Théry, 1908, Steraspis laetitia Curletti, 2011, and Steraspis modesta Kerremans, 1895. One of the goals of these field observations was to increase the knowledge of the biology of these common but localized species. In May 2011, an adult of $S$. infuscata was discovered inside the taproot of a Combretum collinum Fresen. (Combretaceae) sapling. This well-developed adult was found seven centimeters below the soil surface and ready to emerge. Prior to pupation, the mature larva had cut along the bottom of the taproot, thus facilitating the emergence of the adult.

Résumé. - A propos de la biologie de Steraspis infuscata Théry et des références sur d'autres espèces de Steraspis collectées au Bénin (Coleoptera, Buprestidae). Au Bénin, quatre espèces de Steraspis Dejean, 1883, ont été capturées dans le centre et le nord du pays : Steraspis fastuosa Gerstaecker, 1871, Steraspis infuscata Théry, 1908, Steraspis laetitia Curletti, 2011, et Steraspis modesta Kerremans, 1895. Une des finalités de ces observations était d'essayer de mieux connaître la biologie de ces espèces parfois communes mais souvent localisées. En mai 2011, nous avons eu la chance de trouver un adulte de $S$. infuscata dans le pivot d'un très jeune arbre de Combretum collinum Fresen. (Combretaceae). Parfaitement formé avec les élytres durcis, cet adulte était prêt à prendre son envol. Il était situé à sept centimètres au-dessous de la surface du sol. La larve avait découpé le haut de la racine principale, facilitant ainsi la sortie de l'adulte.
\end{abstract}

Keywords. - Buprestidae, Steraspis, biology, ecology, development, taproot, host plant, Combretum, Benin.

Steraspis are large species of buprestid beetles belonging to the subfamily Chrysochroinae, subtribe Eucallopistina (BELLAMY, 2008), most recently revised by CURLETTI (2009), with nearly all species restricted to habitats in sub-saharan Africa, while two [Steraspis speciosa (Klug, 1829) and S. squamosa (Klug, 1829)] are known from parts of North Africa and the Middle East. These beetles are difficult to catch during the warmth of the day because of their large eyes and excellent vision as they are highly alert and quickly fly when approached. The first goal of this project was to locate and identify host plant species. Moreover, trying to capture them during the day can be a real sport. For high trees a long-handled tropics net was usually needed. Beating the trees at dawn may be really profitable as they would more likely be too cold to escape.

Although many adults have been captured all over Africa, little is known about the biology of the species of Steraspis (CURLETTI, 2009), especially in West Africa; few data on their host plants are available. For instance, Steraspis (Steraspis) speciosa was recorded from Acacia raddiana Savi in desert areas of southern Morocco (MATEU, 1972). S. (S.) squamosa was recorded from Tamarix gallica L. in Israel (HALPERIN, 1976) and from Tamarix spp. in Egypt (HAGAG et al., 1996). In Mauritania, we collected three specimens of S. squamosa on Tamarix senegalensis DC (R.I.M., Nouakchott: 25.XI.1987, JFV coll.). Another large species, 
Steraspis ambigua (Fåhraeus, 1851) was collected at rest, mating and feeding on the leaves of Combretum molle R. Br. ex G. Don. and Terminalia sericea Burch ex DC (BELlaMY et al., 1988) in South Africa. In Mauritania, we collected several specimens of Steraspis speciosa on Acacia raddiana in Trarza (R.I.M., Tiguent: 20.X.1987; 04.XI.1987, JFV coll.), and also on Acacia nilotica (L.) Willd. ex Del. in Gorgol (R.I.M., Maghama: 26.IX.1988, JFV coll.). The larval damage of $S$. speciosa and the emergence holes of adults were clearly visible on the main branches of these Acacia species.

In Benin, four species of Steraspis have been found: Steraspis (Steraspis) fastuosa Gerstaecker, 1871, S. (Pissteras) infuscata Théry, 1908, S. (Pissteras) laetitia Curletti, 2011, and S. (Steraspis) modesta Kerremans, 1895. The first three species were collected in the north (departments of Atacora, Borgou) and are widespread during the rainy season but not very numerous. The last one, collected in the center of Benin (department of Collines), is localized and scarce.

In Benin, nothing is known about the biology and the ecology of Steraspis spp. Looking for their larvae and their host plants was always a goal during the collecting trips in Benin for several years. In this note, we present a short list of Steraspis species captured with their localities, dates and tree species on which they were collected. Discovering their larval hosts remains one of the main goals.

\section{MATERIAL AND METHODS}

Field observations on Steraspis adults and their host feeding. - The first objective concerns an inventory of all tree species on which the Sterapis species can be found. In most cases these beetles eat, rest and mate sometimes on the same tree species. As in most of the northern sites, $S$. infuscata and $S$. modesta have been seen to eat and rest on trees of the family Combretaceae. So an inventory was taken in 2011 of all the Combretum and Terminalia species where Steraspis adults can be found.

Research of immature stages in the soil. - The second objective was to look for larvae and adults inside the prospective host species. During the year, the first Steraspis adults are usually captured in late May or early June according to the species. The last adults can be captured until mid-November. Thus, it is very important to conduct host species investigations prior to adult emergence in late May. Earlier this year, several days (11-13.V.2011) were spent investigating in the area of Tanguieta species of Combretaceae on which $S$. infuscata and $S$. modesta can be found. During these three days, we explored the branches and the trunk to be sure that larvae were not living in the upper part of the tree. As predicted, it was found that larvae develop in the lower part of the tree which resulted in the soil at the base of each tree species being excavated. While the goal was to investigate 100 trees per species per day, only 50 trees of each species per day were excavated (total of 200 trees per day).

\section{RESULTS}

Field observations on adults and their host feeding. - These beetles were captured on several trees species from the plant families Combretaceae (Combretum, Terminalia) and Fabaceae (Acacia). In the departments of Atacora (Tanguieta, Nanebou) and Borgou (Kika, Sirarou, Ina, N'Dali, Koroborou, Tchatchou, Papane), Steraspis infuscata was collected on four tree species: Combretum collinum Fresen. (fig. 1-2) near the mountain Atacora (fig. 3), Combretum fragrans F. Hoffm., Terminalia albida Sc. Elliot and Terminalia avicennioides Guill. \& Perr.

In the departments of Atacora (Tanguieta, Nanebou) and Borgou (Kika, Kpessou-Samari, Bétérou, Ina, N'Dali, Komiguea, Koroborou, Thatchou, Papane), Steraspis modesta was collected on six tree species: Combretum collinum, $C$. fragrans, $C$. micranthum, $C$. nigricans Lepr. ex Guill. \& Perr., Terminalia albida and T. avicennioides and Steraspis fastuosa was collected on one tree species: Acacia hockii De Wild. 


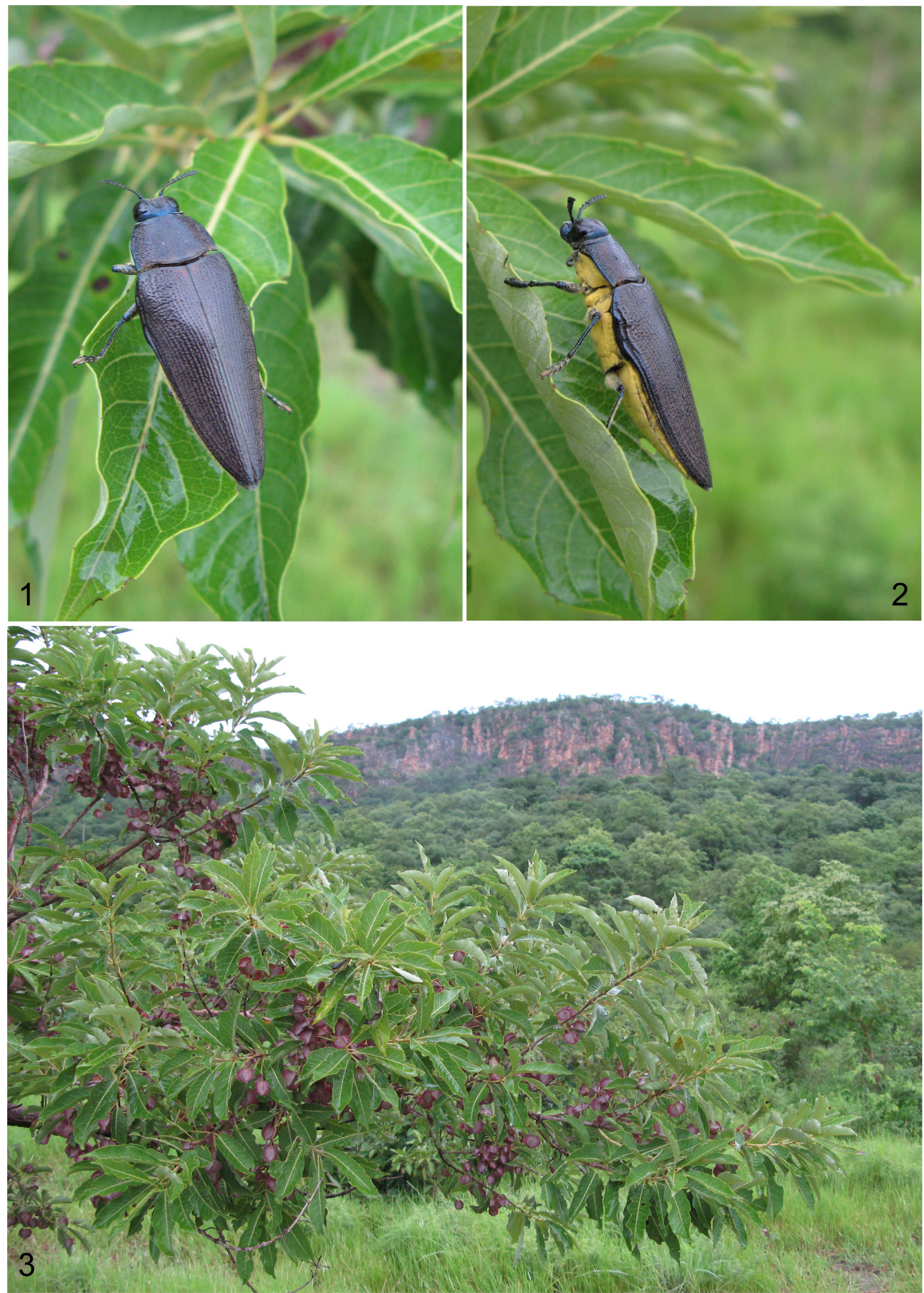

Fig. 1-3. - 1-2, Steraspis infuscata Théry, 1908, on Combretum collinum Fresen. near Tanguieta (Atacora). -3 , Young Combretum collinum at the basis of the mountain Atacora. 
In the department of Collines (Akofodioulé), Steraspis laetitia was only collected on one tree species: Terminalia glaucescens Planch.

On these trees, adults of Steraspis were observed resting, eating the leaves and also sometimes mating. A list of these captures is given (Table I).

Table I. - List of localities and dates for captures of Steraspis spp. in Benin (2005-2010).

\begin{tabular}{|c|c|c|c|c|c|c|c|c|c|}
\hline Species & \begin{tabular}{|c|}
$\begin{array}{c}\text { Climatic } \\
\text { zone }\end{array}$ \\
\end{tabular} & $\begin{array}{c}\text { Depart- } \\
\text { ment }\end{array}$ & Locality & $\begin{array}{l}\text { Date of } \\
\text { capture }\end{array}$ & $\begin{array}{c}\text { Trees on which they } \\
\text { were captured }\end{array}$ & Family & Longitude & Latitude & $\begin{array}{c}\text { Altitude } \\
(\mathrm{m})\end{array}$ \\
\hline \multirow{17}{*}{$\begin{array}{l}\text { Steraspis } \\
\text { infuscata }\end{array}$} & Sudanian & Atacora & Tanguieta & 27.VI.2010 & Combretum collinum & Combretaceae & $10^{\circ} 3653 " \mathrm{~N}$ & $1^{\circ} 16^{\prime} 20^{\prime \prime} \mathrm{E}$ & 246 \\
\hline & Sudanian & Atacora & Tanguieta & 27.V.2009 & Combretum collinum & Combretaceae & $10^{\circ} 363^{\prime} 3^{\prime \prime} \mathrm{N}$ & $1^{\circ} 16^{\prime} 20^{\prime \prime} \mathrm{E}$ & 246 \\
\hline & \begin{tabular}{|l|} 
Sudanian \\
\end{tabular} & Atacora & \begin{tabular}{|l|} 
Tanguieta \\
\end{tabular} & 31.X.2009 & Combretum collinum & Combretaceae & $10^{\circ} 3653 " \mathrm{~N}$ & $1^{\circ} 16^{\prime} 20^{\prime \prime} \mathrm{E}$ & 246 \\
\hline & Sudanian & Atacora & Tanguieta & 28.VII.2007 & Combretum fragrans & Combretaceae & $10^{\circ} 366^{\prime} 53 " \mathrm{~N}$ & $1^{\circ} 16^{\prime} 20^{\prime \prime} \mathrm{E}$ & 246 \\
\hline & Sudanian & Atacora & Nanebou & 1.VIII.2009 & Combretum collinum & Combretaceae & $10^{\circ} 59^{\prime} 48^{\prime \prime} \mathrm{N}$ & $1^{\circ} 31^{\prime} 52^{\prime \prime} \mathrm{E}$ & 257 \\
\hline & $\begin{array}{l}\text { Sudano- } \\
\text { Guinean }\end{array}$ & Borgou & Kika & 25.VI.2006 & Terminalia albida & Combretaceae & $9^{\circ} 23^{\prime} 17^{\prime \prime N}$ & $2^{\circ} 07^{\prime} 13^{\prime \prime} \mathrm{E}$ & 371 \\
\hline & $\begin{array}{l}\text { Sudano- } \\
\text { Guinean }\end{array}$ & Borgou & Kika & 16.VIII.2005 & Combretum collinum & Combretaceae & $9^{\circ} 23^{\prime} 13^{\prime \prime} \mathrm{N}$ & $2^{\circ} 07^{\prime} 15^{\prime \prime} \mathrm{E}$ & 371 \\
\hline & $\begin{array}{l}\text { Sudano- } \\
\text { Guinean }\end{array}$ & Borgou & Sirarou & 9.VIII.2006 & Combretum collinum & Combretaceae & $9^{\circ} 50^{\prime} 34^{\prime \prime} \mathrm{N}$ & $2^{\circ} 59^{\prime} 01 " \mathrm{E}$ & 353 \\
\hline & \begin{tabular}{|l|} 
Sudano- \\
Guinean
\end{tabular} & Borgou & Sirarou & 9.VIII.2006 & Terminalia albida & Combretaceae & $9^{\circ} 50^{\prime} 34^{\prime \prime} \mathrm{N}$ & $2^{\circ} 59^{\prime} 01 " \mathrm{E}$ & 353 \\
\hline & $\begin{array}{l}\text { Sudano- } \\
\text { Guinean }\end{array}$ & Borgou & Ina & 8.VIII.2006 & Combretum collinum & Combretaceae & $9^{\circ} 59^{\prime} 39^{\prime \prime} \mathrm{N}$ & $2^{\circ} 52^{\prime} 48^{\prime \prime} \mathrm{E}$ & 388 \\
\hline & $\begin{array}{l}\text { Sudano- } \\
\text { Guinean }\end{array}$ & Borgou & N'Dali & 8.VIII.2006 & Combretum fragrans & Combretaceae & $9^{\circ} 55^{\prime} 50^{\prime \prime} \mathrm{N}$ & $2^{\circ} 57^{\prime} 19 " \mathrm{E}$ & 390 \\
\hline & $\begin{array}{l}\text { Sudano- } \\
\text { Guinean }\end{array}$ & Borgou & Koroborou & 10.VII.2006 & Combretum collinum & Combretaceae & $9^{\circ} 17^{\prime} 41 " \mathrm{~N}$ & $2^{\circ} 57^{\prime} 08^{\prime \prime} \mathrm{E}$ & 362 \\
\hline & $\begin{array}{l}\text { Sudano- } \\
\text { Guinean }\end{array}$ & Borgou & Koroborou & 10.VII.2006 & Terminalia albida & Combretaceae & $9^{\circ} 17^{\prime} 41 " \mathrm{~N}$ & $2^{\circ} 57^{\prime} 08^{\prime \prime} \mathrm{E}$ & 362 \\
\hline & $\begin{array}{l}\text { Sudano- } \\
\text { Guinean }\end{array}$ & Borgou & Tchatchou & 25.VI.2006 & $\begin{array}{c}\text { Terminalia } \\
\text { avicennioides }\end{array}$ & Combretaceae & $9^{\circ} 16^{\prime} 00^{\prime \prime} \mathrm{N}$ & $2^{\circ} 55^{\prime} 10^{\prime \prime} \mathrm{E}$ & 365 \\
\hline & $\begin{array}{l}\text { Sudano- } \\
\text { Guinean }\end{array}$ & Borgou & Papane & 9.VII.2006 & $\begin{array}{l}\text { Terminalia } \\
\text { avicennioides }\end{array}$ & Combretaceae & $8^{\circ} 42^{\prime} 03^{\prime \prime} \mathrm{N}$ & $2^{\circ} 58^{\prime} 20^{\prime \prime} \mathrm{E}$ & 350 \\
\hline & $\begin{array}{l}\text { Sudano- } \\
\text { Guinean }\end{array}$ & Borgou & Papane & 16.VII.2006 & Combretum collinum & Combretaceae & $8^{\circ} 42^{\prime} 19^{\prime \prime} \mathrm{N}$ & $2^{\circ} 59^{\prime} 10^{\prime \prime} \mathrm{E}$ & 350 \\
\hline & $\begin{array}{l}\text { Sudano- } \\
\text { Guinean }\end{array}$ & Borgou & Papane & 9.VII.2006 & Combretum collinum & Combretaceae & $8^{\circ} 42^{\prime} 03^{\prime \prime} \mathrm{N}$ & $2^{\circ} 58^{\prime} 20^{\prime \prime} \mathrm{E}$ & 350 \\
\hline \multirow{12}{*}{$\begin{array}{c}S . \\
\text { modesta }\end{array}$} & Sudanian & Atacora & Tanguieta & 31.X.2009 & Combretum collinum & Combretaceae & $10^{\circ} 366^{\prime} 3^{\prime \prime N}$ & $1^{\circ} 16^{\prime} 20^{\prime \prime} \mathrm{E}$ & 246 \\
\hline & Sudanian & Atacora & Tanguieta & 31.X.2009 & Combretum fragrans & Combretaceae & $10^{\circ} 3653 " \mathrm{~N}$ & $1^{\circ} 16^{\prime} 20^{\prime \prime} \mathrm{E}$ & 246 \\
\hline & Sudanian & Atacora & Nanebou & 31.X.20009 & Combretum collinum & Combretaceae & $10^{\circ} 59 ' 50 " \mathrm{~N}$ & $1^{\circ} 31^{\prime} 52^{\prime \prime E}$ & 257 \\
\hline & $\begin{array}{l}\text { Sudano- } \\
\text { Guinean }\end{array}$ & Borgou & Kika & 16.VIII.2005 & Combretum collinum & Combretaceae & $9^{\circ} 23^{\prime} 13^{\prime \prime} \mathrm{N}$ & $2^{\circ} 07^{\prime} 15^{\prime \prime} \mathrm{E}$ & 371 \\
\hline & \begin{tabular}{|l|} 
Sudano- \\
Guinean
\end{tabular} & Borgou & Kika & 25.VI.2006 & Terminalia albida & Combretaceae & $9^{\circ} 23^{\prime} 17^{\prime \prime N}$ & $2^{\circ} 07^{\prime} 13 " \mathrm{E}$ & 371 \\
\hline & \begin{tabular}{|l|} 
Sudano- \\
Guinean \\
\end{tabular} & Borgou & $\begin{array}{c}\text { Kpessou- } \\
\text { Samari } \\
\end{array}$ & 13.VII.2006 & Combretum collinum & Combretaceae & $9^{\circ} 30^{\prime} 00^{\prime \prime} \mathrm{N}$ & $2^{\circ} 17 ' 31 " \mathrm{E}$ & 380 \\
\hline & $\begin{array}{l}\text { Sudano- } \\
\text { Guinean }\end{array}$ & Borgou & Bétérou & 25.VI.2006 & $\begin{array}{l}\text { Combretum } \\
\text { micranthum }\end{array}$ & Combretaceae & $9^{\circ} 17^{\prime} 14^{\prime \prime} \mathrm{N}$ & $2^{\circ} 27^{\prime} 18 " \mathrm{E}$ & 363 \\
\hline & $\begin{array}{l}\text { Sudano- } \\
\text { Guinean }\end{array}$ & Borgou & Ina & 8.VIII.2006 & Terminalia albida & Combretaceae & $9^{\circ} 59^{\prime} 39^{\prime \prime} \mathrm{N}$ & $2^{\circ} 52^{\prime} 48 " \mathrm{E}$ & 387 \\
\hline & $\begin{array}{l}\text { Sudano- } \\
\text { Guinean }\end{array}$ & Borgou & Ina & 8.VIII.2006 & Combretum collinum & Combretaceae & $9^{\circ} 59^{\prime} 39^{\prime \prime} \mathrm{N}$ & $2^{\circ} 52^{\prime} 48 " \mathrm{E}$ & 387 \\
\hline & $\begin{array}{l}\text { Sudano- } \\
\text { Guinean }\end{array}$ & Borgou & N'Dali & 24.VII.2008 & $\begin{array}{c}\text { Terminalia } \\
\text { avicennioides }\end{array}$ & Combretaceae & $9^{\circ} 55^{\prime} 51^{\prime \prime} \mathrm{N}$ & $2^{\circ} 57^{\prime} 07^{\prime \prime} \mathrm{E}$ & 390 \\
\hline & $\begin{array}{l}\text { Sudano- } \\
\text { Guinean } \\
\end{array}$ & Borgou & Komiguea & 25.VII.2007 & Combretum nigricans & Combretaceae & $9^{\circ} 23^{\prime} 16^{\prime \prime} \mathrm{N}$ & $2^{\circ} 59^{\prime} 43^{\prime \prime} \mathrm{E}$ & 370 \\
\hline & $\begin{array}{l}\text { Sudano- } \\
\text { Guinean }\end{array}$ & Borgou & Koroborou & 10.VII.2006 & Combretum collinum & Combretaceae & $9^{\circ} 17^{\prime} 01 " \mathrm{~N}$ & $2^{\circ} 07^{\prime} 08^{\prime \prime} \mathrm{E}$ & 362 \\
\hline
\end{tabular}




\begin{tabular}{|c|c|c|c|c|c|c|c|c|c|}
\hline & $\begin{array}{l}\text { Sudano- } \\
\text { Guinean }\end{array}$ & Borgou & Tchatchou & 24.VII.2008 & $\begin{array}{l}\text { Terminalia } \\
\text { avicennioides }\end{array}$ & Combretaceae & $9^{\circ} 16^{\prime} 00^{\prime \prime} \mathrm{N}$ & $2^{\circ} 55^{\prime} 03^{\prime \prime} \mathrm{E}$ & 365 \\
\hline & $\begin{array}{l}\text { Sudano- } \\
\text { Guinean }\end{array}$ & Borgou & Papane & 16.VII.2006 & Combretum collinum & Combretaceae & $8^{\circ} 42^{\prime} 19^{\prime \prime} \mathrm{N}$ & $2^{\circ} 59^{\prime} 10^{\prime \prime} \mathrm{E}$ & 350 \\
\hline & $\begin{array}{l}\text { Sudano- } \\
\text { Guinean }\end{array}$ & Borgou & Papane & 9.VII.2006 & $\begin{array}{c}\text { Terminalia } \\
\text { avicennioides }\end{array}$ & Combretaceae & $8^{\circ} 42^{\prime} 03^{\prime \prime} \mathrm{N}$ & $2^{\circ} 58^{\prime} 20^{\prime \prime} \mathrm{E}$ & 350 \\
\hline \multirow{6}{*}{$\begin{array}{c}S . \\
\text { fastuosa }\end{array}$} & Sudanian & Atacora & Tanguieta & 15.X.2010 & Acacia hockii & Fabaceae & $10^{\circ} 36 ' 53 " \mathrm{~N}$ & $1^{\circ} 16^{\prime} 20^{\prime \prime} \mathrm{E}$ & 246 \\
\hline & Sudanian & Atacora & Tanguieta & 15.VIII.2010 & Acacia hockii & Fabaceae & $10^{\circ} 36 ' 53 " \mathrm{~N}$ & $1^{\circ} 16^{\prime} 20^{\prime \prime} \mathrm{E}$ & 246 \\
\hline & Sudanian & Atacora & Tanguieta & 1.XI.2009 & Acacia hockii & Fabaceae & $10^{\circ} 36 ' 53 " \mathrm{~N}$ & $1^{\circ} 16^{\prime} 20^{\prime \prime} \mathrm{E}$ & 246 \\
\hline & Sudanian & Atacora & Tanguieta & 1.VIII.2009 & Acacia hockii & Fabaceae & $10^{\circ} 36 ' 53 " \mathrm{~N}$ & $1^{\circ} 16^{\prime} 20^{\prime \prime} \mathrm{E}$ & 246 \\
\hline & Sudanian & Atacora & Tanguieta & 26.IX.2007 & Acacia hockii & Fabaceae & $10^{\circ} 36^{\prime} 53 " \mathrm{~N}$ & $1^{\circ} 16^{\prime} 20^{\prime \prime E}$ & 246 \\
\hline & Sudanian & Atacora & Nanebou & 26.IX.2007 & Acacia hockii & Fabaceae & $10^{\circ} 59^{\prime} 50^{\prime \prime} \mathrm{N}$ & $1^{\circ} 31^{\prime} 52^{\prime \prime} \mathrm{E}$ & 257 \\
\hline $\begin{array}{c}S . \\
\text { laetitia }\end{array}$ & Guinean & Collines & $\begin{array}{l}\text { Akofo- } \\
\text { dioulé }\end{array}$ & 16.V.2011 & $\begin{array}{l}\text { Terminalia } \\
\text { glaucescens }\end{array}$ & Combretaceae & $7^{\circ} 55^{\prime} 27^{\prime \prime} \mathrm{N}$ & $2^{\circ} 17^{\prime} 34^{\prime \prime} \mathrm{E}$ & 196 \\
\hline
\end{tabular}

Research of immature stages in the soil. - A number of trees were targeted for the excavation of soil at their base to allow the roots and lower trunk of each tree to be stripped. During this work, many insects were found belonging to other beetle families including: Bostrichidae, Carabidae, Cerambycidae, Elateridae and Scarabaeidae.

Much of this exploratory work took place at several sites near Tanguieta, and yet the only positive record was from a sapling of Combretum collinum (fig. 4) just before mid-May 2011 (14.V.2011). This young tree showed some symptoms of physiological stress with a few yellow leaves, yet no gallery or damage on the stems was observed. It was surprising to see that the C. collinum sapling hosted an imago of Steraspis infuscata (fig. 4), ready to emerge. The specimen was within the pupal chamber in the entirely hollowed-out taproot (fig. 5). The gallery was $20 \mathrm{~cm}$ long and the pupal chamber got about $5 \mathrm{~cm}$. It was noted that the larva had opened the upper part (fig. 5) of the taproot, thus facilitating the emergence of the adult. After leaving the top of the taproot through this window, the adult beetle had only to cross about $4 \mathrm{~cm}$ of soil before reaching the surface. As this adult was completely developed and likely only awaiting an emergence cue, it was good fortune to capture it. After searching for some Steraspis larvae in the soil and/or lower trunk of the trees, a live adult was found inside the taproot of a young tree.

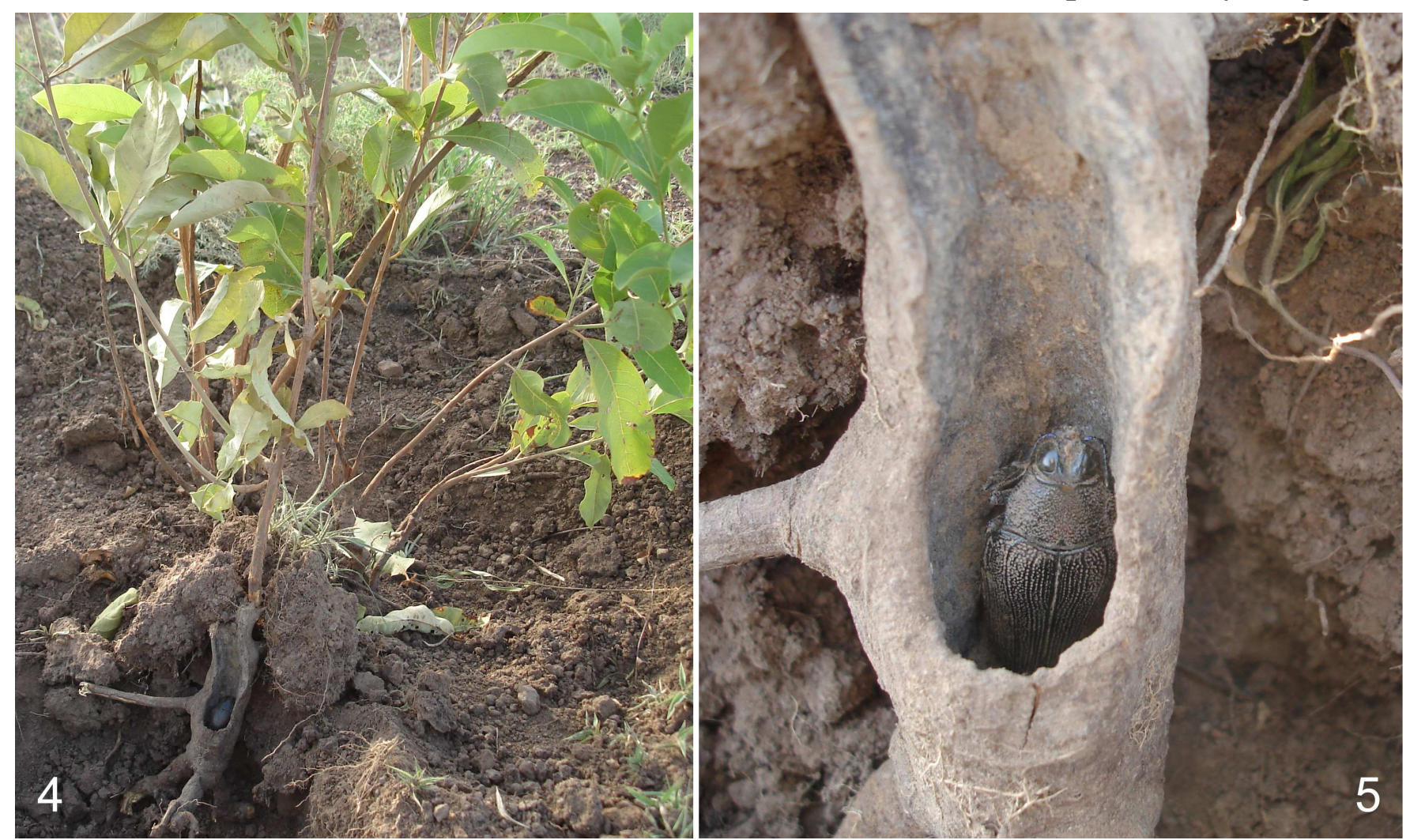

Fig. 4-5. - 4, Young Combretum collinum Fresen. with taproot infested by Steraspis infuscata Théry, 1908. -5 , Living adult of Steraspis infuscata in the taproot of Combretum collinum. 


\section{DISCUSSION}

Few data about the specificity of tropical xylophagous beetles towards forest trees and more generally tropical woody plants are available. About forest trees of tropical areas, one well-known study was done in South America (TAVAKILIAN et al., 1997). Among other results, it showed that a high proportion of species was closely specific to a plant genus or family. Here, this is the case with the specificity of these two species of black Steraspis (S. infuscata and $S$. modesta) to the family Combretaceae. This is also the case with another genus of buprestid, Evides Dejean, 1833, in relation with the plant family Anacardiaceae. For instance, the host tree of Evides pubiventris (Laporte \& Gory, 1835) is Lannea discolor (Sonder) Engl. in South Africa (MACFADYEN et al., 2007) and the host tree of Evides intermedia Saunders, 1874, is Lannea acida A. Rich., in Benin (Kika, Kpessou-Samary: 23.VI.2007, JFV coll.).

In West Africa, the main data about the specificity of xylophagous beetles are provided by DUFFY's synthesis (1980) and by WAGNER et al. (1991). Fourty years ago, a masterpiece was published by MATEU (1972) on the xylophagous study on different trophic levels associated with Saharo-sahelian Acacia species. The biology of Steraspis speciosa is described therein and shows that the egg is deposited on the top of a branch of Acacia raddiana. After emergence, the larvae work their way down inside the branch with visible damage (MATEU, 1972). $S$. speciosa is a primary xylophagous beetle which can inflict serious damage to Acacia trees (MATEU, 1972). This species is quite widespread throughout the Sahara and also common in sahelian zones from western to eastern Africa (DESCARPENTRIES, 1976).

In West Africa, the few data we have shown that:

- S. speciosa lives inside the branches and/or trunk of Acacia spp.;

- S. squamosa lives inside the branches-trunk of Tamarix senegalensis DC.

But for many other West African species of Sterapis, their host-trees are yet to be determined. So, our observation seems to be the first one of a Steraspis species living below the soil surface until emergence. In the future, confirmation of this biological trait of $S$. infuscata in the $C$. collinum taproot will be sought and while finding the host trees of $S$. modesta and $S$. fastuosa in the same locality is continued.

Many xylophagous beetles are good flyers showing high dispersal capacity in the habitat. Dispersion behavior seems conditioned by the necessity of having good oviposition sites for future generations but also for nutritional needs (MATEU, 1972; HANKS, 1999). According to HANKS (1999), if the same woody plant can harbor the larva and is also eaten by the adult, then the xylophagous species is more sedentary. In fact, we could have sedentary populations of good flyers of $S$. infuscata in Tanguieta where $C$. collinum is quite common.

Generally, adults of xylophagous beetles are highly attracted by allelochemical compounds emitted by trees under physiological stress (ALLISON et al., 2004). This may be the case with Steraspis infuscata because this little, stunted tree demonstrated an external sign of weakness (i. e. yellow leaves). By the way the larvae of Steraspis can also reinforce this statement. These plant symptoms could be used in the future to select the target trees with more effectiveness. Other field experiments at different times of the year could yield interesting data on larval development. After this preliminary study the discovery of the larval stages may occur and therefore yield a more complete life-cycle of this species as well as the other Steraspis species from Benin.

ACKNOWLEDGMENTS. - We would like to thank M. Gianfranco Curletti (Museo Civico di Storia Naturale Carmagnola) for determining most of the Sterapis species we collected in Benin. Many thanks also to MM. Lazard Adoho and Djassibou Boundja for helping us in the field.

\section{REFERENCES}

Allison J. D., Borden J. H. \& SeYbold S. J., 2004. - A review of the chemical ecology of the Cerambycidae (Coleoptera). Chemoecology, 14: 123-150. 
Bellamy C. L., 2008. - A World Catalogue and Bibliography of the Jewel Beetles (Coleoptera: Buprestoidea). Volume 1: Introduction; Fossil Taxa; Schizopodidae; Buprestidae: Julodinae - Chrysochroinae: Poecilonotini. Pensoft Series Faunistica, 76, 625 p. Pensoft Publishers, Sofia-Moscow.

Bellamy C. L., WeSTCOTT R. L. \& VeRITY D. S., 1988. - New synonymy, distributional and adult and larval host records for some southern African Buprestidae (Coleoptera). The Coleopterists Bulletin, 42: 73-83.

Curletti G., 2009. - Sul genere Steraspis Dejean, 1833 (Coleoptera, Buprestidae). Boletin del Museo Regionale di Scienze Naturale di Torino, 26 (1-2): 83-153.

DESCARPENTRIES A., 1976. - Contribution à l'étude biologique du Sénégal septentrional. XXIX. Coléoptères Buprestidae. Bulletin de l'Institut Fondamental d'Afrique Noire, (A) 38 (1): 124-134.

DUFFY E. A. J., 1980. - A monograph of the immature stages of African timber beetles (Cerambycidae), Supplement. London: British Museum of Natural History, $190 \mathrm{p}$.

Hagag S. M., Girgis G. N., BATT A. M. \& OKIL A. M., 1996. - Biological studies on the tamarisk Jewel borer, Steraspis squamosa Klug (Coleoptera Buprestidae) in Egypt. Egyptian Journal of Agricultural Research, 74 (4): 1013-1020.

HALPERIN J., 1976. - The biology of the tamarisk buprestid - Steraspis squamosa - Gan Vanof, 3: 232-240.

HANKS L. M., 1999. - Influence of the larval host plant on reproductive strategies of cerambycid beetles. Annual Review of Entomology, 44: 483-505.

MacFadyen D. N., Reilly B. K., Bellamy C. L. \& Eiselen R. J., 2007. - Morphological differences between three South Africa species of Evides Dejean, 1833 (Coleoptera: Buprestidae). The Coleopterists Bulletin, 61 (4): 509-517.

MAteU J., 1972. - Les insectes xylophages des Acacia dans les régions sahariennes. Publicações do Instituto de Zoologica "Dr. Augusto Nobre" Faculdade de Ciêmcoas do Porto, 116, 57 (1-4): 189-332.

TAVAKIlian G., Berkov A. MEURER Grime B. \& Mori S., 1997. - Neotropical tree species and their faunas of xylophagous longicorns (Coleoptera: Cerambycidae) in French Guiana. The Botanical Review, 63 (4): 303-355.

Wagner M. R., Atuahene S. K. N. \& Cobbinah J. R., 1991. - Forest entomology in West tropical Africa: Forest Insects of Ghana. Dordrecht, Kluwer Academic Publishers, 210 p. 